\title{
INTERAKSI ANTARA REMAJA, AYAH, DAN SEKOLAH SERTA HUBUNGANNYA DENGAN TINGKAT STRES DALAM MENGHADAPI UJIAN NASIONAL PADA SISWA SMA
}

\author{
Interactions between Senior High School Students and Their Fathers and School and \\ Its Relationship with Level of Stress Facing High School National Examinations
}

\author{
DIAH KRISNATUTI PRANADJI ${ }^{1 *}$, ASROHENI MUHARRIFAH ${ }^{2}$ \\ ${ }^{1}$ Staf Pengajar Departemen Ilmu Keluarga dan Konsumen, Fakultas Ekologi Manusia, \\ Institut Pertanian Bogor, Jalan Lingkar Kampus IPB Dramaga, \\ Bogor 16680 \\ ${ }^{2}$ Departemen IImu Keluarga dan Konsumen, Fakultas Ekologi Manusia, Institut Pertanian \\ Bogor, Kampus Dramaga, Bogor 16680
}

\begin{abstract}
National Examination is one of reference of evaluation to increase the quality of education in Indonesia. In High School National Examination 2009, there is increasing of the amount of examination subjects. Those were become six subjects from only three in the previous year. The students in the third year who facing the National Examination was easier to get stress. Stress level in them can be minimalized by their interaction with family and school environtment. The research design was cross sectional study with 76 high school students as samples that determined by simple random sampling. Analysis data consisted of Independent sample's difference T-test and Mann Whitney, Spearman's correlation, and multiple linear regretion. The result of this research showed that stress level in girls were higher than boys. The result also showed that stress was caused by less interaction with father and school. Parenting which tend to mutual and communicative interaction with father would also give a better interaction quality. If father could optimize his role to do a good parenting, their children would also overcome their stress well.
\end{abstract}

\section{Key words: father, high school, interaction, national examination, stress}

\section{PENDAHULUAN}

Sumberdaya manusia (SDM) yang berkualitas merupakan modal dasar untuk mewujudkan manusia seutuhnya dan masyarakat seluruhnya. Hal ini berarti bahwa kualitas sumberdaya manusia dipengaruhi oleh kualitas pendidikannya. Ujian Nasional (UN) dijadikan sebagai bahan acuan evaluasi untuk meningkatkan kualitas pendidikan dan menyiapkan peserta didik agar dapat bersaing di dunia internasional. Pada pelaksanaan UN 2009 terjadi penambahan mata pelajaran dari tiga menjadi enam di tingkat sekolah menengah atas. $\mathrm{Pe}-$ nambahan mata pelajaran tersebut dinilai dapat meningkatkan beban kejiwaan siswa terutama beban psikologis (Sudaryanto 2008).

Dalam tahap perkembangannya, jiwa remaja mengalami kondisi emosi yang tidak stabil dan cenderung sensitif terhadap semua hal yang berkaitan dengan pribadinya. Siswa SMA kelas tiga yang sedang menghadapi Ujian Nasional lebih rentan terkena stres. Tingkat stres remaja dapat diminimalkan dengan interaksi oleh keluarga dan lingkungan sekolah.

Berkaitan dengan peran orangtua, dalam keluarga biasanya ayah berperan sebagai pengambil keputusan untuk mengatur atau mengelola sumberdaya yang terbatas untuk mencapai tujuan bersama. Walaupun ibu lebih sering berinteraksi dengan anak, namun biasanya ayah yang paling menentukan dalam pengambilan keputusan dan kontrol disiplin mengenai berbagai permasalahan yang timbul dalam keluarga (Sarwono 2007). Hal ini akan mempengaruhi harapan yang diberikan ayah terhadap remaja. Arus informasi dapat mempengaruhi hubungan interaksi ayah dengan remaja. Pada era keterbukaan informasi seperti saat ini, ayah tidak lagi mengkomunikasikan harapannya dan memahami kebutuhan terhadap remaja 
sehingga akan sulit bagi ayah dan anak untuk mencapai tingkat pemahaman terhadap apa yang dipikirkan dan dirasakan satu sama lain.

Pada penelitian Putri dan Ling (2009), diungkap pula bahwa nilai orangtua (familyparental value) merupakan moderator parsial yang signifikan untuk menengahi hubungan antara keluarga-sekolah dan keluargamasyarakat terkait dengan gaya pengasuhan. Hal ini dapat diartikan bahwa orangtua memiliki peran yang sangat besar dalam mempengaruhi interaksi anak (remaja) baik dengan lingkungan sekolah maupun dengan lingkungan masyarakat.

Selain itu, lingkungan sekolah juga berpengaruh cukup besar terhadap perkembangan jiwa remaja karena hampir sepertiga dari waktu setiap hari dilewatkan di sekolah. Guru menjadi tokoh utama di sekolah yang mempengaruhi perkembangan kepribadian anak remaja secara menyeluruh. Lingkungan pergaulan dengan teman sebaya pun besar pengaruhnya terhadap sikap, minat, penampilan, dan tingkah lakunya untuk mengikuti perubahan yang lebih luas pada masa selanjutnya. Berdasarkan paparan tersebut, maka sangat menarik untuk menganalisis interaksi antara remaja dan ayah serta sekolah, dan juga hubungannya dengan tingkat interaksi antara remaja dan stres dalam menghadapi Ujian Nasional (UN).

Penelitian ini secara umum bertujuan untuk mengetahui interaksi antara remaja, ayah, dan sekolah serta hubungannya dengan tingkat stres dalam menghadapi Ujian Nasional pada siswa SMA Negeri dan SMA Swasta. Secara khusus, penelitian ini bertujuan: (1) mengidentifikasi karakteristik contoh dan karakteristik keluarga contoh; (2) mengidentifikasi interaksi contoh dengan ayah; (3) mengidentifikasi interaksi contoh di lingkungan sekolah; (4) mengindentifikasi prestasi belajar contoh; (5) membandingkan tingkat stres contoh; dan (6) menganalisis hubungan berbagai variabel dan faktor-faktor yang mempengaruhi tingkat stres contoh dalam penelitian.

\section{METODE}

\section{Desain, Lokasi, dan Waktu}

Metode yang digunakan dalam penelitian ini adalah metode survey dengan desain penelitian cross sectional study. Penelitian ini dilakukan di SMA Negeri 3 dan SMA Insan Kamil, Kota Bogor, Jawa Barat.
Contoh siswa yang terlibat dalam penelitian ini berasal dari dua sekolah tersebut yang dipilih secara simple random sampling. Penentuan sekolah didasarkan secara purposive berdasarkan sekolah favorit di kota tersebut yang mana SMA Negeri 3 Bogor merepresentasikan sekolah negeri favorit di Kota Bogor dan SMA Insan Kamil merepresentasikan sekolah swasta favorit. Pengumpulan data dilakukan selama bulan April hingga Juni 2009.

\section{Contoh dan Cara Penarikan Contoh}

Kriteria contoh dalam penelitian ini adalah anak yang berusia 16-18 tahun atau remaja pertengahan (remaja/siswa kelas III SMA). Alasan pemilihan contoh ini adalah karena anak remaja atau siswa kelas III SMA sedang menghadapi Ujian Nasional (UN) sesuai dengan tujuan yang ingin dicapai dalam penelitian ini. Pada tahap awal penentuan contoh dilakukan proses penyaringan siswa melalui penyebaran kuesioner untuk mengidentifikasikan siswa yang memiliki ayah. Dari proses penyaringan tersebut, ternyata hanya 81 siswa yang mengisi kuesioner dengan benar dan lengkap beserta rapor semester akhir. Selanjutnya 81 siswa tersebut diambil dengan proporsi jenis kelamin yang sama baik laki-laki maupun perempuan sehingga total contoh dalam penelitian ini adalah sebanyak 76 siswa, yaitu 38 siswa laki-laki dan 38 siswa perempuan, yang dipilih secara simple random sampling.

\section{Jenis dan Cara Pengumpulan Data}

Data yang dikumpulkan terdiri dari data primer dan data sekunder. Data primer meliputi identitas pribadi, karakteristik sosial ekonomi keluarga, interaksi anak (dengan lingkungan keluarga/ayah dan lingkungan sekolah), prestasi belajar, dan tingkat stres contoh. Data sekunder yang digunakan adalah keadaan umum sekolah berdasarkan informasi yang diperoleh dari Dinas Pendidikan Kota Bogor. Selain itu, data sekunder juga diperoleh dari website sekolah dan keterangan pihak sekolah serta rapor siswa.

\section{Pengolahan dan Analisis Data}

Data yang diperoleh selanjutnya akan diolah melalui proses editing, coding, scoring, entry data ke komputer, cleaning dan analisis data. Pada awalnya data dari kuesioner ditransfer ke dalam program Microsoft Excel dan SPSS for windows. 
Analisis data yang dilakukan meliputi statisitika deskriptif (rata-rata, nilai minimum, nilai maksimum, dII) dan inferensia (uji beda, korelasi, dan regresi).

\section{HASIL DAN PEMBAHASAN}

\section{Karakteristik Contoh}

Jenis Kelamin dan Usia Contoh. Proporsi contoh berdasarkan jenis kelamin seimbang antara laki-laki dengan perempuan. Usia contoh di kedua sekolah berkisar antara 16-18 tahun dan lebih dari separuh contoh $(73,7 \%)$ di kedua sekolah berusia 17 tahun.

Urutan Kelahiran. Separuh contoh (50\%) di SMA Negeri 3 tergolong pada kategori anak tengah dan hampir separuh contoh $(47,4 \%)$ di SMA Insan Kamil tergolong pada kategori anak sulung.

Kepribadian. Sebagian besar contoh (76,3\% SMA Negeri 3 dan 84,2\% SMA Insan Kamil) dominan pada tipe kepribadian ekstrovert.

Tujuan Hidup dan Cita-cita. Tujuan hidup dan cita-cita dapat dikelompokkan menjadi tujuan yang berkaitan dengan pendidikan tinggi, bekerja mencari nafkah, prestasi, budi pekerti, menghindari masalah dengan sekolah, dan kemapanan materi. Sebaran contoh berdasarkan tujuan hidup dan cita-cita dapat dilihat pada Tabel 1.

Apabila dikelompokkan menjadi tiga kategori, sebagian besar contoh di SMA Negeri $3(84,2 \%)$ dan lebih dari setengah contoh di SMA Insan Kamil (71,1\%) termasuk ke dalam kategori cukup penting untuk mempunyai tujuan hidup dan cita-cita.

\section{Karakteristik Orangtua}

Besar Keluarga. Lebih dari separuh contoh $(71,1 \%$ di SMA Negeri 3 dan $65,8 \%$ di SMA Insan Kamil) berasal dari keluarga dengan ukuran sedang (5-6 orang), sementara 26,3\% keluarga (baik keluarga contoh di SMA Negeri 3 maupun di SMA Insan Kamil) merupakan kategori keluarga kecil ( $\leq 4$ orang).

Usia Orangtua Contoh. Usia ayah contoh berkisar antara 38 tahun hingga 70 tahun. Hampir seluruh contoh $(97,4 \%$ di SMA Negeri 3 dan $94,7 \%$ di SMA Insan Kamil) memiliki ayah dengan kategori usia dewasa madya (41-65 tahun). Selain itu, sebagian besar usia ibu contoh (82,9\% di SMA Negeri 3 dan $73,7 \%$ di SMA Insan Kamil) juga tergolong usia dewasa madya (41-65 tahun).

Pendidikan Orangtua. Tingkat pendidikan ayah contoh dalam penelitian ini pada umumnya adalah perguruan tinggi (68,4\% di SMA Negeri 3 dan $39,5 \%$ di SMA Insan Kamil). Namun, keragaan responden menunjukkan bahwa tingkat pendidikan ayah contoh pada SMA Negeri 3 lebih tinggi dibandingkan SMA Insan Kamil. Persentase tertinggi tingkat pendidikan ibu contoh $(40 \%$ di SMA Negeri 3 dan $57,9 \%$ di SMA Insan Kamil) adalah tamat SMA. Uji beda Mann Whitney menunjukkan adanya perbedaan $(p<0,05)$ pendidikan ayah contoh di kedua sekolah.

Tabel 1. Sebaran contoh berdasarkan tujuan hidup dan cita-cita

\begin{tabular}{|c|c|c|c|c|c|c|}
\hline \multirow{2}{*}{ Pernyataan } & \multicolumn{6}{|c|}{ Persentase (\%) } \\
\hline & & $\mathbf{A}$ & B & C & D & $E$ \\
\hline 1. Meneruskan ke perguruan tinggi & & 0,0 & 0,0 & 0,0 & 21,1 & 78,9 \\
\hline 2. Bekerja mencari nafkah & & 1,3 & 2,6 & 13,2 & 31,6 & 51,3 \\
\hline 3. Belajar yang rajin agar nilainya bagus & & 0,0 & 0,0 & 3,9 & 42,1 & 53,9 \\
\hline 4. Beraktivitas di sekolah dengan baik & & 0,0 & 1,3 & 15,8 & 56,6 & 26,3 \\
\hline 5. Menghindari masalah di sekolah & & 1,3 & 2,6 & 13,2 & 40,8 & 42,1 \\
\hline 6. Berbakti pada orangtua dan guru & & 0,0 & 0,0 & 0,0 & 26,3 & 73,7 \\
\hline 7. Bertanggung jawab atas segala perbuatan & & 0,0 & 0,0 & 5,3 & 42,1 & 52,6 \\
\hline 8. Berteman dengan baik & & 0,0 & 0,0 & 9,2 & 39,5 & 51,3 \\
\hline 9. Menabung dan hidup hemat & & 0,0 & 2,6 & 15,8 & 32,9 & 48,7 \\
\hline 10.Menjadi orang kaya dan sukses & & 1,3 & 1,3 & 7,9 & 39,5 & 50,0 \\
\hline \multicolumn{7}{|l|}{ Keterangan : } \\
\hline A : Tidak penting & 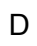 & \multicolumn{5}{|c|}{ Penting } \\
\hline B : Kurang penting & $E$ & \multirow{2}{*}{\multicolumn{5}{|c|}{ Sangat penting }} \\
\hline C : Cukup penting & & & & & & \\
\hline
\end{tabular}



Pekerjaan Utama Orangtua. Persentase terbesar ayah contoh di SMA Negeri 3 memiliki pekerjaan utama sebagai karyawan swasta $(36,8 \%)$, sedangkan di SMA Insan Kamil sebagian besar bekerja sebagai pegawai negeri, wiraswasta dan karyawan swasta dengan proporsi yang sama yaitu masing-masing $26,3 \%$. Sementara itu, lebih dari separuh ibu contoh $(62,9 \%$ di SMA Negeri 3 dan $68,4 \%$ di SMA Insan Kamil) memiliki pekerjaan utama sebagai lbu Rumah Tangga (IRT) atau tidak bekerja.

Pendapatan Keluarga. Pendapatan keluarga pada penelitian ini didapatkan dari jumlah penghasilan semua anggota keluarga (ayah, ibu, dan anggota lainnya) per bulan. Persentase terbesar pendapatan keluarga per bulan pada keluarga contoh di kedua sekolah yaitu terletak pada kisaran Rp 2.500.001,00 sampai Rp 5.000.000,00 (34,2\% di SMA Negeri 3 dan $50 \%$ di SMA Insan Kamil).

\section{Interaksi Contoh dengan Ayah \\ Interaksi Contoh dengan Ayah.} Interaksi contoh dengan ayah dalam penelitian ini diukur dengan dua dimensi, yaitu dimensi kehangatan dan kekerasan. Dalam dimensi kehangatan, proporsi terbesar contoh baik SMA Negeri 3 maupun SMA Insan Kamil menyatakan bahwa ayahnya sering bertanya mengenai mata pelajaran Ujian Nasional (UN) yang sedang contoh hadapi $(44,7 \%$ dan $21,1 \%)$, mendiskusikan mengenai rencana jangka pendek setelah UN kepada contoh $(34,2 \%$ dan $39,5 \%$ ), dan cukup dalam hal ayah membantu contoh belajar, seperti membelikan buku-buku soal UN untuk contoh kerjakan $(39,5 \%$ dan $23,7 \%)$, serta memberikan pujian atau hadiah untuk memotivasi contoh belajar $(36,8 \%$ dan $28,9 \%)$. Walaupun lebih dari setengah contoh $(47,4 \%$ dan $55,3 \%)$ menyatakan bahwa ayah mereka tidak pernah menemani contoh belajar untuk menghadapi UN.

Begitu pula sebaliknya, dimensi kehangatan juga terjadi pada interaksi antara contoh dengan ayah. Interaksi antara contoh dengan ayah menunjukkan bahwa proporsi terbesar contoh di SMA Negeri 3 dan SMA Insan Kamil cukup mempedulikan masalah ayah $(55,3 \%$ dan $44,7 \%)$, berbuat sesuatu yang membuat ayah merasa bangga dan disayang $(55,3 \%$ dan $50 \%)$, mendiskusikan keinginan contoh dengan ayah $(39,5 \%$ dan $28,9 \%$ ), dan memberikan pujian atau hadiah untuk membuat ayah bahagia $(34,2 \%$ dan
$47,4 \%$ ), serta sering membantu ayah bila ayah memerlukan sesuatu $(47,4 \%$ dan $36,8 \%$ ).

Sementara itu, dalam dimensi kekasaran, proporsi terbesar contoh di SMA Negeri 3 dan SMA Insan Kamil menyatakan ayah tidak pernah marah-marah untuk memaksa belajar $(52,6 \%$ dan $50 \%)$, membentak contoh dengan marah $(47,4 \%$ dan $44,7 \%$ ) dan bertengkar dengan contoh jika tidak menuruti perintahnya $(39,5 \%$ dan $47,4 \%)$. Namun, terdapat contoh $(23,7 \%$ di SMA Negeri 3 dan $47,4 \%$ di SMA Insan Kamil) yang menyatakan bahwa ayahnya cukup mengkritik perbuatan contoh saat nilainilainya buruk. Adanya interaksi timbal balik antara ayah dengan anak yaitu kekasaran yang dilakukan ayah menyebabkan adanya kekasaran pula yang dilakukan contoh. Sementara itu, proporsi terbesar contoh di SMA Negeri 3 dan SMA Insan Kamil dalam hal dimensi kekasaran menunjukkan bahwa contoh tidak pernah marah-marah $(52,6 \%$ dan $65,8 \%)$, membentak $(73,7 \%$ dan $76,3 \%)$, dan bertengkar $(44,7 \%$ dan $68,4 \%)$ dengan ayahnya. Hampir separuh contoh $(47,4 \%$ dan $31,6 \%$ ) jarang mengkritik perbuatan ayah.

Apabila dikategorikan menjadi tiga kategori, maka persentase terbesar contoh (73,7\% di SMA Negeri 3 dan $76,3 \%$ di SMA Insan Kamil) memiliki interaksi dengan ayah cukup baik. Berdasarkan hasil uji statistik, diketahui bahwa tidak ada perbedaan yang signifikan dalam hal interaksi pada dimensi kehangatan dan kekasaran antara contoh di SMA Negeri 3 dan SMA Insan Kamil terhadap ayahnya, begitu pula sebaliknya.

Komunikasi Contoh dengan Ayah. Komunikasi yang selalu dilakukan contoh di SMA Negeri 3 dengan ayahnya menyebar dalam berbagai waktu yaitu setiap hari berkomunikasi $(26,3 \%)$, saat makan bersama $(21,1 \%)$, saat menjelang tidur $(2,6 \%)$, saat belajar di rumah $(2,6 \%)$, saat menonton TV $(31,6 \%)$, saat di perjalanan $(15,8 \%)$, saat di tempat kerja $(7,9 \%)$, dan saat di luar kota $(7,9 \%)$. Sama halnya pada contoh di SMA Insan Kamil, komunikasi yang sering dilakukan dengan ayahnya menyebar pada setiap hari berkomunikasi $(23,7 \%)$, saat makan bersama $(13,2 \%)$, saat menjelang tidur $(2,6 \%)$, saat belajar di rumah $(2,6 \%)$, saat menonton TV $(13,2 \%)$, saat di perjalanan $(23,7 \%)$, saat di tempat kerja $(2,6 \%)$, dan saat di luar kota $(2,6 \%)$. Apabila contoh dikelompokkan menjadi tiga kategori, maka lebih dari separuh contoh (71,7\%) memiliki komunikasi dengan ayah cukup 
baik. Hal ini berarti bahwa contoh telah berkomunikasi cukup baik dengan ayah saat belajar di rumah dan saat dalam perjalanan menjelang UN.

Keeratan Interaksi Contoh dengan Ayah. Contoh baik di SMA Negeri 3 Bogor dan SMA Insan Kamil menyatakan setuju jika ayah bisa diajak mengobrol tentang apa saja seperti kawan dekat (39,5\% dan $44,7 \%)$, dapat merasakan kalau ada kesulitan tanpa diberitahu $(36,8 \%$ dan $47,4 \%)$, menceritakan bila mempunyai masalah $(26,3 \%$ di kedua sekolah), selalu membantu menyelesaikan masalah yang terjadi $(55,3 \%$ dan $47,4 \%)$, menyemangati saat gagal $(47,4 \%$ dan $50 \%)$, bangga dengan kemampuan yang contoh miliki $(57,9 \%$ dan $68,4 \%)$, paling tahu akan hobi contoh $(47,4 \%$ dan $44,7 \%)$, memberikan uang jajan tambahan $(36,8 \%$ dan $39,5 \%)$, memantau akitivitas contoh di luar jam sekolah $(28,9 \%$ dan $42,1 \%)$, dan mengenal teman-teman contoh $(34,2 \%$ dan $47,4 \%)$.

Apabila keeratan contoh dengan ayah dikelompokkan menjadi tiga kategori, maka hasil menunjukkan bahwa sebagian besar contoh $(81,6 \%$ di SMA Negeri 3 dan $76,3 \%$ di SMA Insan Kamil) memiliki keeratan interaksi dengan ayah cukup baik. Hal ini berarti bahwa contoh merasa cukup dekat dengan ayah ketika ayah menjadi teman paling dekat, ayah tempat mencurahkan masalah dan membantu menyelesaikan masalah, mengetahui apa yang dirasakan, mengetahui teman terdekat, serta mengetahui dan memantau aktvitas diluar jam sekolah. Selain itu, terdapat 13,2\% contoh (di masing-masing sekolah) yang memiliki keeratan kurang baik dengan ayahnya. Hal ini menunjukkan bahwa contoh kurang dekat dengan ayah dan menilai ayah kurang sebagai tempat mencurahkan masalah dan membantu menyelesaikan masalah, kurang mengetahui apa yang dirasakan, kurang mengetahui teman terdekat, serta kurang mengetahui dan memantau aktivitas diluar jam sekolah.

Kualitas Interaksi dengan Ayah. Hasil penelitian menunjukkan bahwa hampir setengah contoh di SMA Negeri 3 dan SMA Insan Kamil merasa puas $(34,2 \%$ dan $39,5 \%)$ dan bahagia $(36,8 \%$ dan $44,7 \%)$ terhadap kualitas interaksi yang terjalin antara contoh dengan ayah. Apabila kualitas interaksi dengan ayah dikelompokkan menjadi tiga kategori, maka persentase tertinggi contoh (65,8\% di SMA Negeri 3 dan $42,1 \%$ di SMA Insan Kamil) termasuk kategori cukup puas/bahagia. Hal ini berarti contoh merasa cukup puas terhadap interaksi ayah yang baik dan cukup merasakan interaksi dengan ayah terjalin dengan kebahagiaan dalam memenuhi kebutuhan fisik dan psikologis menjelang UN.

Harapan Ayah. Pada umumnya, ayah contoh menilai setuju apabila contoh harus menuruti perintah orangtua agar lulus UN (52,6\% di SMA Negeri 3 dan 57,9\% di SMA Insan Kamil), pergaulannya harus selalu dipantau menjelang UN (50\% di SMA Negeri 3 dan $52,6 \%$ di SMA Insan Kamil), contoh harus bisa menjadi bintang kelas atau berprestasi agar nilai UN bagus $(44,7 \%$ di SMA Negeri 3 dan $52,6 \%$ di SMA Insan Kamil), dan contoh harus masuk perguruan tinggi setelah UN (50\% di SMA Negeri 3 dan $52,6 \%$ di SMA Insan Kamil). Harapan ayah dilihat dari aspek ekonomi, dapat diketahui bahwa ayah contoh tidak setuju jika contoh harus mempunyai pekerjaan dan penghasilan sendiri setelah UN $(68,4 \%$ di SMA Negeri 3 dan $73,3 \%$ di SMA Insan Kamil) dan membantu ekonomi orangtua setelah UN $(84,2 \%$ di SMA Negeri 3 dan $78,9 \%$ di SMA Insan Kamil). Sementara itu, ayah contoh $(73,7 \%$ di SMA Negeri 3 dan $44,7 \%$ di SMA Insan Kamil) setuju jika tidak lulus UN, anak bisa menyita uang orangtua.

Harapan ayah dilihat dari aspek sosial menunjukkan bahwa, proporsi terbesar ayah contoh menyatakan setuju merasakan kebahagiaan jika anaknya lulus UN $(57,9 \%$ di SMA Negeri 3 dan $39,5 \%$ di SMA Insan Kamil), anak dapat meningkatkan status sosial keluarga $(60,5 \%$ di SMA Negeri 3 dan $63,2 \%$ di SMA Insan Kamil), anak sebagai pelindung keluarga $(52,6 \%$ di SMA Negeri 3 dan $47,4 \%$ di Insan Kamil), anak mempererat interaksi keluarga $(65,8 \%$ di SMA Negeri 3 dan $60,5 \%$ di SMA Insan Kamil), dan anak dapat membuat hidup terasa lengkap (50\% di SMA Negeri 3 dan $44,7 \%$ di SMA Insan Kamil). Harapan ayah dilihat dari aspek religius menunjukkan bahwa, sebagian besar ayah contoh $(84,2 \%$ di SMA Negeri 3 dan $81,6 \%$ di SMA Insan Kamil) sangat menyetujui anak adalah titipan Tuhan yang harus dijaga. Selain itu, harapan ayah dilihat dari segi psikologis, persentase terbesar ayah contoh $(63,2 \%$ di SMA Negeri 3 dan $44,7 \%$ di SMA Insan Kamil) menyatakan setuju jika tidak lulus UN, anak dapat menyebabkan bertambahnya beban tanggungan keluarga. Sebanyak $44,7 \%$ ayah contoh di SMA Negeri 3 dan 39,5\% ayah contoh di SMA Insan Kamil menyatakan tidak 
setuju apabila anak dapat membuat stres jika tidak lulus UN.

Apabila dikelompokkan menjadi tiga kategori, sebagian besar ayah contoh (75\%) memiliki harapan sedang. Hal ini menunjukkan bahwa ayah memiliki harapan yang cukup besar terhadap anaknya di masa depan setelah lulus Ujian Nasional. Hal ini diduga karena prestasi akademik anak termasuk kategori baik di sekolah favorit sehingga ayah cukup yakin anaknya akan berhasil.

\section{Interaksi Contoh dengan Sekolah}

Interaksi Contoh dengan Guru. Guru memberikan perhatian yang cukup besar kepada siswa dalam proses belajar mengajar. Proporsi terbesar contoh SMA Negeri 3 dan SMA Insan Kamil menyatakan bahwa guru sering memperhatikan jika ada siswa yang bertanya (47,4\% dan $57,9 \%)$, memberikan nilai secara objektif $(50 \%$ dan $55,3 \%)$, menyampaikan pelajaran terlalu cepat dan sulit dipahami (50\% dan 36,8\%), serta memuji dan bangga jika melakukan hal yang baik $(39,5 \%$ dan $18,4 \%)$. Interaksi contoh dengan guru juga menunjukkan bahwa proporsi terbesar contoh SMA Negeri 3 dan SMA Insan Kamil menilai jarang terjadi guru menyuruh belajar sendiri saja jika sulit mengerti pelajaran yang diajarkan $(42,1 \%$ dan $47,4 \%$ ) dan guru tidak mempunyai waktu untuk mendengarkan keluhan $(42,1 \%$ dan $39,5 \%)$.

Apabila contoh dikelompokkan menjadi tiga kategori, maka sebagian besar contoh (68,4\% contoh di SMA Negeri 3 dan 84,2\% contoh di SMA Insan Kamil) termasuk dalam kategori cukup baik berinteraksi dengan guru. Hal ini menunjukkan terjadinya interaksi yang cukup baik antara guru dan contoh seperti guru cukup memperhatikan contoh ketika bertanya, cukup memberikan nilai secara objektif, dan cukup menjadi pendengar yang baik bagi keluhan-keluhan siswanya. Namun, masih terdapat contoh (26,3\% di SMA Negeri 3 dan 7,9\% di SMA Insan Kamil) yang memiliki interaksi yang kurang baik dengan guru. Artinya contoh kurang dapat berinteraksi dengan gurunya dalam hal guru membimbing saat mengalami kesulitan pelajaran dan mendengar keluhankeluhan siswanya.

Interaksi Contoh dengan Teman. Lebih dari setengah contoh $(68,4 \%$ di SMA Negeri 3 dan $65,8 \%$ di SMA Insan Kamil) mempunyai teman baik di sekolah. Sebanyak $57,9 \%$ contoh SMA Negeri 3 dan 42,1\% contoh SMA Insan Kamil memiliki rasa kepercayaan yang tinggi terhadap teman, tetapi ditemukan contoh $(42,1 \%$ di SMA Negeri 3 dan $36,8 \%$ di SMA Insan Kamil) yang terkadang cekcok dengan teman. Walaupun demikian, contoh di SMA Negeri 3 dan SMA Insan Kamil sering berkumpul bersama $(57,9 \%$ dan $42,1 \%)$, berdiskusi mengenai kesulitan belajar $(42,1 \%$ dan $31,6 \%$, dan tidak sulit untuk meminta bantuan kepada teman $(39,5 \%$ dan $34,2 \%)$. Hal ini menunjukkan adanya interaksi contoh dengan teman berlangsung baik yang didasari saling percaya dan menjaga silahturahmi seperti sering berkumpul bersama.

Apabila contoh dikelompokkan menjadi tiga kategori, maka persentase terbesar contoh $(81,6 \%$ contoh di SMA Negeri 3 dan $65,8 \%$ contoh di SMA Insan Kamil) termasuk dalam kategori cukup baik berhubungan dengan teman. Hal ini berarti bahwa terjadi interaksi yang cukup baik dengan teman seperti cukup percaya dengan teman, cukup berdiskusi dengan teman mengenai kesulitan belajar, dan cukup membantu kesulitan teman. Namun, terdapat pula sebanyak 7,9\% contoh SMA Negeri 3 dan 21,1\% contoh SMA Insan Kamil yang termasuk ke dalam kategori kurang baik dalam berhubungan dengan teman. Hal ini menggambarkan bahwa contoh kurang membantu kesulitan teman dan pernah cekcok dengan teman.

Interaksi Contoh dengan Sekolah. Secara umum contoh SMA Negeri 3 dan SMA Insan Kamil menyatakan sangat menyukai sekolah $(52,6 \%$ dan $36,8 \%)$. Hal ini juga tercermin dari jumlah contoh yang menyatakan bahwa fasilitas sekolah menunjang semangat belajar $(57,9 \%$ dan $18,4 \%$ ). Sebanyak $34,2 \%$ menyatakan cukup dekat dengan beberapa guru secara umum. Hal ini didukung oleh pernyataan dari hampir setengah contoh $(42,1 \%$ di SMA Negeri 3 dan $31,6 \%$ di SMA Insan Kamil) setuju memiliki prestasi di sekolah. Hal ini memperlihatkan bahwa secara umum contoh mempunyai interaksi yang baik dengan sekolah. Apabila contoh dikelompokkan menjadi tiga kategori, maka sebagian besar contoh $(89,5 \%$ di SMA Negeri 3 dan $78,9 \%$ di SMA Insan Kamil) memiliki interaksi dengan sekolah cukup baik.

\section{Prestasi Belajar}

Berdasarkan prestasi belajar, penelitian ini menunjukkan bahwa persentase terbesar contoh $(65,8 \%$ di SMA Negeri 3 dan $81,6 \%$ di 
SMA Insan Kamil) memiliki nilai kognitif dengan kategori sedang (65-80). Prestasi akademik berdasarkan nilai psikomotorik menunjukkan bahwa setengah contoh di SMA Negeri 3 memiliki proporsi yang sama dengan kategori sedang dan tinggi, sedangkan lebih dari separuh contoh di SMA Insan Kamil (60,5\%) memiliki kategori sedang. Nilai afektif contoh di SMA Negeri 3 tergolong kategori baik $(78,9 \%)$, sedangkan lebih dari separuh contoh di SMA Insan Kamil $(57,9 \%)$ tergolong kategori baik sekali. Hasil uji Mann-Whitney menunjukkan bahwa adanya perbedaan yang nyata $(p<0,01)$ pada nilai rapor dengan kategori nilai kognitif di kedua sekolah. Sementara itu, tidak terdapat perbedaan $(p>0,05)$ pada nilai rapor dengan kategori nilai psikomotorik dan nilai afektif di kedua sekolah. Hal ini diduga bahwa ada satu contoh yang memiliki nilai yang rendah pada SMA Insan Kamil. Satu contoh tersebut sering absen di kelas sehingga contoh tidak bisa mengikuti pelajaran yang diberikan guru.

\section{Tingkat Stres}

Gejala stres yang sering kali dialami oleh hampir setengah contoh SMA Negeri 3 adalah merasa pegal-pegal pada leher/punggung/bahu $(34,2 \%)$, merasa tidak tenang/tegang/cemas/terancam/gelisah $(31,6 \%)$, merasa sukar berkonsentrasi dalam belajar $(34,2 \%)$, dan merasa banyak beban yang menumpuk $(42,1 \%)$. Hal ini berbeda dengan gejala stres yang sering kali dialami oleh contoh di SMA Insan Kamil yang hanya mengalami sukar berkonsentrasi dalam belajar $(34,2 \%)$. Sisanya persentase gejala stres tidak terlalu banyak.

Berdasarkan pernyataan yang diberikan contoh, lebih dari setengah contoh $(59,2 \%)$ yang merasa mengalami sukar berkonsentrasi belajar kemungkinan karena tidak mempunyai jadwal belajar yang jelas dan realistis. Padahal, jika melihat ada atau tidaknya masalah dengan mata pelajaran, maka sebanyak $69,7 \%$ contoh mengaku mempunyai masalah dengan mata pelajaran. Persentase terbesar mata pelajaran yang dirasakan kurang mampu yang diujikan pada Ujian Nasional adalah IImu Pengetahuan Alam (73,7\%). Sebanyak $75 \%$ contoh merasa sistem pendidikan di Indonesia dengan mengadakan Ujian Nasional (UN) tidak tepat. Namun, persentase terbesar contoh $(47,9 \%)$ menargetkan nilai sebesar 9,5 untuk mencapai nilai kelulusan tahun ini.

Penelitian ini juga menunjukkan bahwa, lebih dari setengah contoh $(55,3 \%)$ meng- anggap Ujian Nasional merupakan hal yang menegangkan. Sebanyak 25\% contoh menganggap Ujian Nasional biasa saja. Selain itu, sebanyak $17,1 \%$ contoh menganggap Ujian Nasional merupakan hal yang membuat senang atau semangat. Kesan lainnya, sebanyak $2,6 \%$ contoh merasa campur aduk antara cemas dan senang dalam menghadapi Ujian Nasional. Berbagai cara dilakukan contoh untuk menghilangkan rasa cemas dalam menghadapi Ujian Nasional yaitu dengan cara pergi ke rumah saudara atau teman $(6,6 \%)$, jalan-jalan ke tempat hiburan $(17,1 \%)$, mendekatkan diri kepada Tuhan $(53,9 \%)$ dan lainnya (22,4\%) seperti berinternet, belajar, mendengarkan musik, bermain game, tidur, bercerita kepada orangtua, dan berdiam diri di kamar. Selain itu, persiapan yang dilakukan dalam menghadapi Ujian Nasional yaitu dengan mengikuti bimbingan belajar $(63,2 \%)$, belajar sendiri atau mandiri $(19,7 \%)$, belajar kelompok $(1,3 \%)$, dan lainnya $(15,8 \%)$ seperti belajar dengan guru yang menyenangkan, mengikuti bimbingan belajar, belajar sendiri maupun belajar kelompok, hingga tidak melakukan persiapan apa-apa. Hal ini menggambarkan bahwa contoh dapat mengatur dirinya dan memberi semangat saat menghadapi situasi yang sulit. Tingkat stres contoh kemudian dikelompokkan menjadi tiga kategori, maka persentase terbesar contoh $(73,7 \%$ di SMA Negeri 3 dan $76,3 \%$ di SMA Insan Kamil) berada dalam kategori tingkat stres sedang. Tingkat stres sedang memberikan arti bahwa gejala stres kadang-kadang dialami oleh contoh dalam 6 bulan terakhir. Persentase contoh di SMA Negeri 3 yang mengalami tingkat stres tinggi $(15,8 \%)$ lebih banyak dibandingkan persentase contoh di SMA Insan Kamil $(10,5 \%)$ dalam kategori tersebut.

\section{Hubungan Antar Variabel}

Hubungan Interaksi dengan Sekolah dan Tingkat Stres. Hasil uji korelasi Spearman menunjukkan adanya hubungan yang negatif antara interaksi contoh dengan sekolah terhadap tingkat stres $(p=0,024$; $r=0,259$ ). Hal ini berarti bahwa semakin baik interaksi dengan sekolah, maka tingkat stresnya akan semakin menurun. Hasil penelitian ini didukung oleh Needlman (2004) yang menyatakan bahwa tekanan dalam masalah akademik, keinginan untuk mendapatkan nilai tinggi, atau selalu berusaha agar tidak gagal, merupakan 
sumber stres yang dialami remaja di sekolah.

Hubungan Kepribadian Contoh dan Interaksi dengan Teman. Hasil uji korelasi Spearman menunjukkan adanya hubungan yang positif antara kepribadian contoh terhadap interaksi contoh dengan teman $(p=0,002 ; r=0,349)$. Hal ini berarti bahwa semakin ekstrovert/terbuka, maka interaksi dengan teman akan semakin baik pula. Hasil penelitian ini didukung oleh pernyataan Adelia (2006) bahwa proses sosialisasi yang berjalan tidak sempurna dapat membentuk kepribadian yang menyimpang sehingga dapat melakukan tindakan yang menyimpang pula.

Hubungan Keeratan Contoh-Ayah dan Interaksi Contoh dengan Sekolah. Hasil uji korelasi Spearman menunjukkan adanya hubungan yang positif antara keeratan contoh-ayah dan interaksi contoh dengan sekolah $(p=0,000 ; r=0,412)$. Hal ini berarti bahwa semakin tinggi keeratan dengan ayah, maka semakin baik interaksi contoh dengan sekolah.

Hubungan Keeratan Contoh-Ayah dengan Tujuan dan Cita-cita Contoh. Hasil uji korelasi Spearman menunjukkan adanya hubungan yang positif antara keeratan contoh-ayah dengan tujuan hidup dan citacita $(p=0,006 ; r=0,314)$. Hasil uji ini berarti bahwa semakin erat contoh dengan ayah, maka tujuan hidup dan cita-cita contoh juga semakin tinggi prioritasnya. Dalam hal ini ayah merupakan kepala keluarga yang dianggap paling bertanggung jawab terhadap kelangsungan hidup keluarga. Ayah mempunyai kekuasaan yang dianggap sangat tinggi untuk mengambil keputusan sehingga peran ayah sangat penting bagi perkembangan cita-cita remaja. Anak juga membutuhkan ayah sebagai pengarah pendidikannya dan teladan untuk perannya kelak (Gunarsa \& Gunarsa 2004).

Hubungan Harapan Ayah dengan Tujuan Hidup dan Cita-cita Contoh. Hasil uji korelasi Spearman menunjukkan adanya hubungan positif antara harapan ayah contoh dengan tujuan hidup dan cita-cita $(p=0,001$; $r=0,376$ ). Hal ini berarti bahwa semakin tinggi harapan ayah terhadap contoh, maka tujuan hidup dan cita-cita contoh akan semakin tinggi prioritasnya. Hasil penelitian ini diperkuat oleh Alvin (2007) yang mengemukakan bahwa para orangtua benar-benar menjadi penentu batas-batas pengaruh terhadap anak-anaknya. Tingkat pendidikan orangtua yang semakin tinggi, maka semakin adanya persaingan untuk menghasilkan anak-anak yang memiliki kemampuan dalam berbagai aspek.

\section{Faktor-Faktor yang Berpengaruh terhadap Tingkat Stres}

Dari model regresi linier berganda, variabel jenis kelamin $(p=0,02)$, besar keluarga $(p=0,02)$, kepribadian $(p=0,02)$, interaksi ayah $(p=0,02)$, dan usia ibu $(p=0,03)$ memiliki pengaruh nyata terhadap tingkat stres contoh. Nilai adjusted $R$ Square $\left(R^{2}\right)$ dalam model regresi ini adalah sebesar $32,7 \%$. Hal ini berarti bahwa variabel-variabel yang disusun dalam model penelitian ini hanya dapat menjelaskan $32,7 \%$ dari penyebab stres yang dialami oleh contoh, selebihnya dijelaskan oleh variabel-variabel yang lain di luar model tersebut, misalnya alokasi waktu dan strategi belajar.

\section{KESIMPULAN DAN SARAN}

\section{Kesimpulan}

Hasil penelitian menunjukkan bahwa semakin baik interaksi dengan sekolah, maka tingkat stres contoh akan semakin menurun. Semakin ekstrovert contoh, maka semakin baik interaksi dengan teman. Semakin erat interaksi contoh dengan ayah, maka semakin baik pula interaksi dengan sekolah. Semakin erat interaksi contoh dengan ayah, maka tujuan hidup dan citacita semakin tinggi prioritasnya. Selain itu, semakin tinggi harapan ayah terhadap contoh, maka tujuan hidup dan cita-cita akan semakin tinggi prioritasnya.

Jenis kelamin, besar keluarga, kepribadian, hubungan contoh dengan ayah, dan usia ibu memiliki pengaruh nyata terhadap tingkat stres contoh. Tingkat stres banyak dialami oleh remaja perempuan, berasal dari keluarga dengan ukuran besar, bertipe kepribadian ekstrovert, kurangnya interaksi dengan ayah, dan usia ibu yang lebih muda.

\section{Saran}

Hasil penelitian menunjukkan bahwa interaksi contoh dengan sekolah berhubungan dengan tingkat stres. Oleh karena itu, hendaknya sekolah terutama guru dalam menghadapi Ujian Nasional sudah memberikan persiapan sedini mungkin baik psikis dan mental siswa dengan pendalaman materi dan latihan soal-soal dengan cara menarik sehingga siswa tidak merasa bosan dan jenuh. Selain itu, hasil penelitian menunjukkan bahwa interaksi dengan ayah mem- 
pengaruhi stres anak. Berdasarkan hal ini, ayah hendaknya mempunyai waktu banyak untuk bertukar pikiran, mendukung, dan mengatasi masalah anaknya terutama saat menghadapi Ujian Nasional. Walaupun ibu sebagai pengasuh utama dalam keluarga, tetapi ayah tidak boleh meninggalkan perannya sebagai pengarah perkembangan di masa depan.

\section{DAFTAR PUSTAKA}

Adelia. 2006. Libatkan Ayah dalam Mendidik Anak.

http://www.balipost.co.id/balipostcetak/2 006/9/3/kel3.html. [16 April 2009].
Alvin NG. 2007. Handling Study Stress. Jakarta: PT Elex Media Komputindo.

Gunarsa SD, Gunarsa YSD. 2000. Psikologi Praktis: Anak, Remaja, dan Keluarga. Jakarta: BPK Gunung Mulia.

Needlman R. 2004. Adolescent Stress. http://www.drspock.com/article.html. [16 Juni 2009].

Putri SS, Ling LS. 2009. Parenting Style in Family with Adolescent Child: Family Ecology Perspective. Jurnal IImu Keluarga dan Konsumen 2:101-110.

Sarwono SW. 2007. Psikologi Remaja. Jakarta: PT. Raja Grafindo Persada.

Sudaryanto. 2008. UN \& Dualisme Pembelajaran. www.pelita.or.id [21 Desember 2008].

${ }^{*}$ Korespondensi :

Telp : +62-251 8628303

Email:diahkp@yahoo.com 